\title{
Psychology and Theodicy in Aquinas
}

\author{
JOHN R. BOWLIN \\ University of Tulsa
}

Throughout much of this century the most prominent exegetes maintained that Aquinas's mature moral psychology is fundamentally voluntarist, that he considers the will an independent cause of action, most conspicuously in his later works. Disagreement over the character of the will's causal authority and the composition of the list of later works did little to unsettle their shared conviction that Aristotle's intellectualist moral psychology was improved, indeed saved, by Aquinas's insistence that the will can move itself, at least in some fashion, apart from the influence of the intellect. ${ }^{1}$

More recently intellectualist interpretations have been defended and found favor. J. B. Korolec, Alan Donagan, and others have argued that Aquinas not only reduces the will to a passive power, subject to the intellect's control, but he also has no reason to give it independent causal authority. ${ }^{2}$ The criticisms of intellectualism that preceded and followed the condemnation of 1277 provided such a reason, or so the defenders of the new consensus contend, which explains why Scotus offers a voluntarist account of human action while Aquinas does not. ${ }^{3}$ In fact, Aquinas's insistence that

Stanley Hauerwas, Russell Hittinger, Gene Rogers, John Taylor, and an anonymous reviewer read an earlier draft. I am grateful for their comments and criticisms.

1. See Rene Antoine Gauthier and Jean Yves Jolif, Aristote: L'éthique à Nicomaque, 2nd ed., vol. 2 (Paris: Béatrice-Nauwelaerts, 1970), p. 218; Bernard Lonergan, Grace and Freedom: Operative Grace in the Thought of St. Thomas Aquinas, ed. J.P. Burns (New York: Herder and Herder, 1971), pp. 93-97; Odom Lottin, "La Preuve de al Liberté Humaine chez Saint Thomas d'Aquin," Recherches de Theologie Ancienne et Medievale 23 (1956): 323-30; and Klaus Riesenhuber, Die Transzendenz Der Freiheit Zum Guten: Der Wille in der Anthropologie und Metaphysik des Thomas von Aquin (Munchen: Berchmanskolleg Verlag, 1971), p. 290.

2. J. B. Korolec, "Free Will and Free Choice," in The Cambridge History of Later Medieval Philosophy, ed. Norman Kretzmann, Anthony Kenny, and Jan Pinborg (Cambridge: Cambridge University Press, 1982), pp. 629-41; Alan Donagan, "Thomas Aquinas on Human Action," in The Cambridge History of Later Medieval Philosophy, pp. 642-54.

3. See Korolec, "Free Will," p. 636-37. Indeed, he could not. Voluntarism arose in the late thirteenth century in response to doubts about the will's freedom that Aquinas did not share. Voluntarists asked questions that he did not address. Bonnie Kent's excellent study, Virtues of the Will: The Transformation of Ethics in the Late Thirteenth Century ([Washington, D.C.: The Catholic University Press of America, 1995], 
the intellect determines the will's activity can be found among the articles condemned, and of course, it is unfettered activity that Scotus's voluntarism secures for the will. ${ }^{4}$

When disagreement among exegetes runs this deep, suspicion of the alternatives they offer seems justified, as does desire for novel exegesis. In a recent effort Daniel Westberg follows suspicion to novelty, arguing that Aquinas so deftly incorporates intellect and will in his treatment of human action that his moral psychology is no more intellectualist than voluntarist. ${ }^{5}$ To think that Aquinas's moral psychology gives special prominence to either intellect or will, ignores the complexity of his view, the even-handedness of his treatment. Indeed, by Westberg's lights it was precisely this kind of inattention that, in part, precipitated the condemnation of 1277 and the voluntarist backlash that followed. ${ }^{6}$ Korolec, Donagan, and the rest make an equivalent failure today and invite similar responses. Those convinced of Aquinas's intellectualist credentials but unsympathetic with a moral psychology that denies autonomy to the will may be tempted to defend something like Scotus's voluntarism. Those convinced that intellectualist readings of Aquinas's moral psychology underestimate the autonomy he in fact gives to the will may be tempted to defend interpretations that return us to the voluntarist consensus of mid-century. ${ }^{7}$ Westberg's goal is to sidestep this tedious exchange by insisting that such alternatives are mistakenly regarded as exclusive.

In what follows I argue that neither the new intellectualist consensus nor the exegetical innovation that Westberg defends captures the full complexity of Aquinas's view. In fact, his moral psychology has both intellectualist and voluntarist features, and he resorts to each as needed in order to follow human agency from creation to redemption. Explicating the biblical narrative is what matters, and Aquinas's unrefined moral psychology offers the collection of tools he needs to describe the different things that human beings do under Providence. ${ }^{8}$ Recognizing that the descriptive task before him is too complex and too varied for any one of the tools at his disposal,

pp. 94-149) makes this much plain. Still, Aquinas may have had good reason to withhold doubt and ample resources to address these new questions. See below.

4. See esp. articles 162-65, 173.

5. Daniel Westberg, Right Practical Reason: Aristotle, Action, and Prudence in Aquinas (Oxford: Clarendon Press, 1994). Westberg is not the first to try this tack. See Servais Pinckaers, The Sources of Christian Ethics, trans. Mary Thomas Noble (Washington, D.C.: The Catholic University of America Press, 1995), pp. 379-92.

6. Westberg, Right Practical Reason, pp. 110-15.

7. Some take both approaches. See Patrick Lee, "The Relation Between Intellect and Will in Free Choice According to Aquinas and Scotus," Thomist 49 (1985): $321-42$.

8. Mark Jordan concurs: Aquinas, he contends, does moral psychology from the outside, as it were, positing internal powers of this or that sort as needed in order to account for the various things God's creatures do. See Mark Jordan, Ordering Wisdom: The Hierarchy of Philosophical Discourses in Aquinas (Notre Dame: University of Notre Dame Press, 1986), pp. 142-48. 
Aquinas refuses to refine what he has, to combine and synthesize these intellectualist and voluntarist features. Exegetes should follow his lead. Better to see that he appeals to the intellectualist moral psychology that he inherits from Aristotle in order to describe the basic features of human action in via while resorting to Augustine's Stoic-inspired voluntarism in order to account for Adam's fall from grace in Eden. To demonstrate this conclusion, I must consider the virtues and vices of both the traditional interpretation and Westberg's innovation.

\section{WHY INTELLECTUALIST INTERPRETATIONS TEMPT VOLUNTARIST REPLIES}

Intellectualist interpretations of Aquinas's moral psychology begin with his insistence that each and every act of the will is necessarily preceded by an apprehension of the will's object-the good-by the intellect. Rational desire follows judgment about the good and the fitting (ST I-II.9.1-2). ${ }^{9}$ Since there is nothing in the will that is not first in the intellect, it follows that the will cannot be regarded as self-moving. It is, rather, a passive power (STI.80.2). 10

Of course, Aquinas does admit that the will moves itself "as to the exercise of its act," but this caveat concedes very little (ST I-II.9.3.3). He is not saying that the will can specify its own act, that it can determine on its own what end it will desire. The specification of the will's act is derived from its object, the apprehended good, which is presented to it by the intellect (ST I-II.9.1; 10.1-2). Nor is he implying that the will's power over the exercise of its act entails the power to determine whether it will act for the sake of an object specified by the intellect. ${ }^{11}$ Rather, he is saying the will's

9. I consulted the following texts and translations: Quaestiones Disputatae, 2 vols. (Turin: Marietti, 1953); On Evil, trans. Jean Oesterle (Notre Dame, Ind.: University of Notre Dame Press, 1995); The Disputed Questions on Truth, 3 vols., trans. Robert W. Mulligan, James V. McGlynn, and Robert W. Schmidt (Chicago: Henry Regnery Company, 1951-1954); Summa Contra Gentiles, 3 vols. (Turin: Marietti, 1961/1967); Summa Contra Gentiles, 4 vols., trans. A. C. Pegis, J. F. Anderson, V. J. Bourke, and C. J. O'Neil (Notre Dame, Ind.: University of Notre Dame, 1975); Summa Theologiae, 3 vols. (Turin: Marietti, 1950); and Summa Theologica, vol. 5, trans. Fathers of the English Dominican Province (New York: Benziger Bros., 1948).

10. Since Aquinas insists that the appetitive powers are "proportionate to the apprehensive powers" (STI.83.4), he feels compelled to ask whether the will, like the intellect, is divided into active and passive powers (ST I.83.3.obj.3). He replies by reminding us that the intellect moves the will, "and therefore there is no need to distinguish in the will an active and a passive will" (STI.83.4.3). The will is simply passive.

11. Here voluntarist exegetes make their stand. If the will cannot determine whether it desires the object specified by the intellect, it is no longer free. Since Aquinas quite plainly insists that the will is free, it follows that he must assume the will has this kind of power over its acts. See Lonergan, Grace andFreedom, p. 95. Of course, if it turns out that voluntary agency can be secured without assigning this kind of freedom to the will, then no worry remains to generate this exegetical conclusion. 
general desire for some end enables it to act for the sake of that end through the choice of some unspecified means (ST I-II.9.3). Indeed, he is simply stating the obvious: willing the end is a necessary prelude to choosing the means. Velle makes electio possible. ${ }^{12}$ And note, he is not implying that the will determines what means are effective or whether a particular means is in fact chosen. These tasks belong to the intellect, to its deliberation over appropriate means (ST I-II.14.1; 9.4) and to its judgment that some particular means is in fact best (ST I-II.13.3; I.83.3.2). In fact, no specific means can be chosen by the will that the intellect has not first found good and then best. It follows that power over exercise is a thoroughly modest affair, providing neither final nor efficient causal authority with respect to any particular object, but only possibility with respect to choice.

By intellectualist lights, justification for assuming that the will is a passive power follows pragmatically from the demands of describing and explaining actions. An act of the will becomes intelligible once we can say what it is and why it was done. An intention, for example, becomes intelligible once we understand why the will was moved toward some particular end but not others, and we secure this understanding once we locate the object that the intellect has judged good and thus desirable as an end. The good that is apprehended and presented to the will provides a reason that explains what was done precisely because it provides the will with a reason to move in one way and not another. This, at least in part, is what it means to call the will a rational appetite. ${ }^{13}$ Its actions are explained by the reasons that move it to desire this or that, and of course, it is the good apprehended by the intellect that gives it reason to move. A will that somehow managed to move itself-independent of a prior judgment by the intellect about the good-would act, quite literally, without reason. Its movements would be random, its desires unintelligible, irrational.

The most notable implication of this intellectualist account of human action regards human freedom. If every act of the will is specified by an act of the intellect that precedes it, then the character of human agency, including its voluntariness, principally depends upon the intellect. Aquinas concedes as much. Voluntariness, he insists, depends upon knowledge and

12. Aquinas makes the modest character of this caveat abundantly clear in the body of De Malo IV, where he writes, "As to the exercise of the act, first it is clear that the will is moved by itself: for just as it moves the other powers so also does it move itself. . . . For example, from the fact that [a person] wills health, he moves himself to will to take a dose of medicine, for from the fact that the wills health he begins to deliberate about those things that conduce to health, and finally when deliberation is ended he wills to take the dose of medicine; so accordingly the will to take the medicine is preceded by counsel which proceeds from the will of the person who wills to take counsel."

13. "voluntas est appretitus quidam rationalis" (ST I-I.8.1). Literally, will is appetite endowed with a certain rationality. For a fine explication of Aquinas's treatment of rational appetite see David Gallagher, "Thomas Aquinas on the Will as Rational Appetite," Journal of the History of Philosophy 29 (1991): 559-84. 
reason alone. To say that a human action is voluntary entails nothing more than noting that it is done for the sake of an end that is known in a way that permits rational deliberation over the means (ST I-II.6.1-2).

The trouble with this treatment of the voluntary, at least according to Aquinas's Franciscan critics in the late-thirteenth century, is that it does not satisfy our basic sense of what it means for the will to be free, for human action to be voluntary. Stated simply, perhaps simplistically, the worry is twofold. First, if the voluntary is a species of the rational, then the will's indeterminacy, its ability to desire this or that, is dependent upon the ability of the deliberating intellect to regard this or that object as good and thus desirable. Conceding as much, Aquinas writes:

The fact that man is master of his actions, is due to his being able to deliberate about them: for since the deliberating reason is indifferently disposed to opposite things, the will can be inclined to either. ( $S T$ I-II.6.2.2; cf. ST I.82.2.1)

It follows that the will cannot desire opposites simpliciter, on its initiative, but only per accidens. ${ }^{14}$

Second, an intellectualist account of the voluntary compels us to imagine instances when an agent acts knowingly, and yet also with necessity. Again, Aquinas appears to concede the point, noting three such instances. I will mention two now, a third later. The most obvious instance regards an object that is "good universally and from every point of view" (ST I-II.10.2). Here Aquinas has in mind the state of our wills with respect to happiness and the wills of the blessed with respect to God (ST I.82.2). In each case, the will tends (tendet) to its object of necessity precisely because, unlike other objects, these cannot be regarded by the intellect as deficient in some way and set aside in favor of another (ST I-II.10.2).

Less obvious is the conditional necessity that Aquinas finds in the will, the necessitas finis. Here he has in mind those instances where some end "is not to be attained, or so well attained . . . except in one way." Thus for example, "from the will (voluntate) to cross the sea, arises in the will the necessity to wish (velit) for a ship" (ST I.82.1). The simple and absolute desire for one end necessarily generates a simple and absolute desire for another. Here we remain at the level of abstract wishing, of mere wanting to have and not necessarily of intending to have by some particular means. ${ }^{15}$ I want to cross the sea and so I must also want to have a ship. But notice how

14. The language comes from proposition 173 of the condemnation of 1277 , which reads, "That the cognition of contraries is the sole cause why the rational soul can will opposites, and that the power simpliciter cannot will opposites except per accidens and by reason of another one." From James A. Weisheipl, Friar Thomas D'Aquino: His Life, Thought and Works (Washington, D.C.: The Catholic University of America Press, 1974), p. 336.

15. Aquinas distinguishes velle and intentio at ST I-II.8.3; 12.4 . 
the same conditional necessity can apply between intended end and chosen means. If I intend to cross the sea safely I imply that I will do so by choosing some particular means (ST I-II.12.1.4). If, after careful deliberation, I determine that three ships are equally seaworthy, then of course there is no conditional necessity involved when I arbitrarily choose one of them. ${ }^{16}$ However, if I decide that, all things considered, one of the ships is best for the voyage, then it would seem that my choice of that particular ship is necessary, given my intention to cross the sea. In this instance the intended end could not be well attained without this particular choice of means. Moreover, this necessity, while unimaginable apart from my intention to travel, is principally derived from the intellect's judgment about the best means. For, of course, we have seen that it is at least possible for me to intend to cross the sea without my choice of a particular ship being necessary. By contrast, my judgment that one ship is best, given my intention to sail, necessarily precipitates my choice. ${ }^{17}$

The character of the Franciscan complaint should be plain. A will whose indeterminacy is not its own, but derived from the intellect; a will that at times acts of necessity because of the intellect's judgment about the good that has no deficiency, the best that has no rival; a will of this sort cannot be free. The human actions it causes cannot be voluntary. Aquinas disagrees, as we shall see below. Nevertheless, the causal authority he assumes the intellect must have over the will for action to be intelligible does indeed prevent him from regarding the will as a self-determining power and an independent source of action.

Scotus hoped to answer these complaints and reestablish the will in its rightful place as the self-determining source of voluntary human action. The will, he insists, is an active potency, rational and self-determining. Its very nature is to be the free and immediate cause of its own actions. 18 Two implications follow. First, the will's indeterminacy, its ability to desire this or that, is not derived from the intellect's ability to regard this or that potential

16. When counsel finds several ends conducive to the end consent is given to each (ST I-II.15.3.3). Then a decision or judgment (sententia vel iudicium) is made in order to determine which means is best (ST I-II.13.1.2).

17. Proposition 163 of the condemnation reads, "That the will firmly pursues what is firmly believed by reason, and that it cannot abstain from what reason prescribes; this necessity, however, is not coercion, but the nature of the will" (Weisheipl, Friar Thomas D'Aquino, p. 336). For a contemporary statement of this necessity see Donald Davidson, "Freedom to Act," in Essays on Actions and Events (Oxford: Oxford University Press, 1980), pp. 63-81.

18. "ita causa activa ad suam actionem inquantum ipsam elicit videtur immediate se habere; nec est dare aliam causam quare sic elicit nisi quia est talis causa" (Quaestiones in Metaphysicam [hereafter QM] IX.15.2, from Allen B. Wolter ed. and trans., Duns Scotus on the Will and Morality [Washington, D.C.: The Catholic University of America Press, 1986], pp. 150-51). Scotus refers to heat to make the point. Like heat, the will is the sole and immediate cause of its effects, and thus like heat it is nothing but this ability. 
object as good, but rather from the will itself, its own act, its own character. ${ }^{19}$ Second, there can be no instances in which the will acts of necessity as a result of the intellect's judgment about the good. Indeed, according to Joseph Incandela, the majority of Scotus's remarks about the will are designed to display its "ability to step back and control all the attachments and attractions presented by the intellect," even those the intellect has judged perfect and best. 20

Of course, none of this implies that the intellect has no causal significance for Scotus. Like Aquinas, he considers the will powerless to act apart from the intellect's apprehension of the good. It must have its object presented to it by the intellect before it can move at all, surely before it can desire this or that. He also contends that the intellect and its object exercise some efficient causal authority over the will.21 However, unlike Aquinas, Scotus does not think that the intellect's apprehension of the good and its judgment about the best are sufficient to determine in full either the content or the occasion of the will's desire. This task is left to the will alone, as it must, lest the will and its acts become subject to necessity by means of the intellect. Thus, the intellect presents options and the will determines concrete courses of action by choosing among them, if it in fact chooses anything at all.

19. For Scotus it is this ability that distinguishes intellect from will. Like the will, the intellect can be determined in many ways, it can know many things, but it cannot control its own determination. It must wait upon its object, which elicits its act. Nor can it withhold its act of understanding once its object becomes intelligible. Rather, an object made intelligible is known at once. Thus the intellect "does not have it in its power to both understand and not understand; or as regards propositional knowledge, where contrary acts are possible, it does not have the power to both assent and dissent" (QM IX.15.2; Wolter, Duns Scotus, p. 155). By contrast, the will, according to Scotus, can desire something or nothing. If it desires something it could be this or that. In each instance nothing elicits the will's act but the will itself. From this difference Scotus concludes that the will possesses a greater measure of perfection than the intellect (QM IX.15.3; Wolter, Duns Scotus, p. 159), while the intellect, at least in this respect, falls under nature and necessity (QM IX.15.2; Wolter, Duns Scotus, p. 155).

20. Joseph Incandela, "Duns Scotus and the Experience of Human Freedom," Thomist 56 (1992): 229-56, see 234. Regarding desire for an object good from every point of view Scotus writes: "Even though in some object there be the fullness of perfection, still, for the act to be necessary, the potency must tend necessarily to that object. Now whatever be the case with the created will of the blessed and the supernatural perfection by which it tends to that perfect object, we must admit the will of the pilgrim tends to it only contigently, even when it is apprehended in general. For such apprehension is not grounds for making the will love that object necessarily. Neither does the will, given such apprehension, determine itself necessarily, even as it does not necessarily continue to will" (Quaestiones quodlibetales 16.1, from Felix Alluntis and Allan B. Wolter trans., God and Creatures: The Quodlibetal Questions of John Duns Scotus [Washington, D.C.: Catholic University of America Press, 1981], p. 374).

21. Kent, Virtues, pp. 145-48. 
Incandela points out that the scope of the will's freedom in this regard extends to both means and ends, and it is principally here-in the bold assertion that "freedom goes all the way down to the will's choice of ends"- that he finds fault with Scotus's moral psychology. The will cannot possess this grand measure of unfettered freedom, according to Incandela, precisely because we do not. We do not "select de novo" the ends we love; rather, we find ourselves disposed to apprehend some ends as good, but not others, to judge some objects as lovable, but not all. Moreover, we find ourselves disposed to regard some ends as good but not others as a consequence of all kinds of "contingent considerations" beyond our control: the place of our birth, the details of our moral training, and the character of the fortune we have known, both good and ill. Surely, these have more to do with the makeup of our loves and the actual character of our agency than choice that knows no bounds. 22

Incandela is a good enough interpreter of Aquinas to know that this is precisely his view. ${ }^{23}$ Ends as such, Aquinas insists, are not objects of choice or deliberation. They are given and assumed as deliberation and choice proceed (STI-II.13.3; 14.2). The point is not that our loves are incorrigible, that our judgments about their goodness are immune to revision. Rather, the point is that there would be no reason to prefer one course of action in favor of another if there were no ends set in place and secured by habitual love to guide deliberation and choice. By the same token, the reevaluation of any particular end always takes place against a significant backdrop of accepted ends, of provisionally unquestioned loves. It must, for without this backdrop there would be no reason to revise particular loves in one direction and not another (ST I-II.13.3). Indeed, without this backdrop the reevaluation of ends, like the choice of means, would be irrational and thus unintelligible. It would proceed, quite literally, without reason and thus without explanation.

Call this situated freedom, where the will's action takes place and becomes intelligible "in the light of a particular historical situation mediated by the intellect." 24 No doubt, this is Aquinas's view of the will's freedom, a consequence of the authority he gives to the intellect in action. Yet, it is not immediately apparent why we should call the acts of a situated will free. If the ends that I happen to pursue are largely determined by judgments shaped by birth, training, and fortune-all matters outside of my control-then it is not at all clear that it makes sense to consider my pursuits voluntary. Similarly, if my choice of means always takes place against a backdrop of settled judgments and established loves, then it is difficult to see how choice is free, if only because the collection of conducive means will be determined by an end that is given quite apart from choice. No

22. Incandela, "Duns Scotus," pp. 239-41.

23. Incandela, "Duns Scotus," pp. 240-47.

24. Incandela, "Duns Scotus," p. 246. The tag is borrowed from Charles Taylor, Hegel (Cambridge: Cambridge University Press, 1975), p. 558. 
wonder then that Scotus endeavors to remove the will from this uncertain freedom, reassert its absolute autonomy, and diminish the causal significance of the intellect. ${ }^{25}$ No wonder then that so many have hoped to free Aquinas from this confusion by finding a voluntarist moral psychology in his later works. No wonder then that the debate between intellectualists and voluntarists, medieval and modern, theologians and exegetes, is interminable. For of course if the freedom of a situated will is uncertain, so too, we have noted, is the intelligibility of every course of action chosen by a will liberated from every possible situation by its own autonomy.

\section{WESTBERG'S ALTERNATIVE}

Westberg hopes to break this deadlock. From the start it should be noted that he has no sympathy for voluntarism of any kind-neither the voluntarist moral psychologies of Scotus and Ockham, nor the voluntarist account of law and obligation found in Suarez. By the same token he has little patience for voluntarist interpretations of Aquinas's moral psychology, where an independent will takes the conclusions of deliberation and translates them into action through a mediating act of choice. ${ }^{26}$ He quite rightly points out that thinking in these terms makes the moral character of human action almost entirely dependent upon the independent disposition of the will, when in fact Aquinas repeatedly insists that good and evil in human action are "predicated in reference to the reason" (ST I-II.18.5). It follows that it is on the strength of prudence-on the degree to which practical reason is perfected by virtue - that the goodness of human action depends. Indeed, Aquinas remarks that prudence is a necessary virtue precisely because right choice is impossible without it (ST I-II.57.5).

Given these sympathies, one might easily imagine Westberg defending an intellectualist interpretation of Aquinas's moral psychology. As he proceeds there are hints that he in fact assumes the causal (and thus the explanatory) priority of intellect over will, and yet he resists. ${ }^{27}$ In part because he thinks that intellectualist readings disregard Aquinas's subtle blending of intellect and will. In part because he thinks that such readings overlook what he takes to be Aquinas's ingenious treatment of human freedom. In part because he thinks that clearing up these confusions will

25. In the late thirteenth century, worries of precisely this kind were directed toward Aquinas's moral psychology and helped generate voluntarist replies. See Kent, Virtues, pp. 114-15, 226-31.

26. Westberg, Right Practical Reason, pp. 29-30, 35.

27. See Westberg, Right Practical Reason, p. 56. There he writes: "Since willing requires cognition, there can be no question of love without knowledge, no separation of powers, no independence of will and intellect, no retraction of the basic superiority of intellect over will." 
quiet voluntarist complaints with Aquinas's moral psychology, hopefully diffusing the conflict among exegetes and dissolving the ancient debate between defenders and critics of Aquinas's so-called intellectualism.

On all sides the basic conceptual error has been

to conceive the will and intellect to function independently, if not in opposition to each other. When they are pictured as operating sequentially, then it is inevitable that the locus of decision is resolved either by positing a judgment of the intellect followed by an acquiescent will (so that the "real decision" is made by the intellect), or by an intellectual description of options presented with "indifference," leaving the will free to make the decision ("free will").

The basic exegetical error has been failure to see that Aquinas resists this conceptual confusion and insists upon "the complementary relation between reason and will" at each of the stages that constitute a human action. ${ }^{28}$

Consider choice. From the start we find Aquinas insisting that electio, "implies something belonging to the reason or intellect, and something belonging to the will" (ST I-II.13.1). Westberg takes this to mean that in choice neither takes priority over the other. Thus, "reason in some way (my emphasis) precedes the will and specifies its act" by locating its object, the means to be chosen. ${ }^{29}$ The will, of course, follows by tending to the object specified (ST I-II.13.1 and ad 2), and yet Westberg downplays all talk of succession and instead highlights Aquinas's use of the language of form and matter to display the substantial union of intellect and will. Choice is "materially an act of will, but formally an act of the reason" (ST I-II.13.1). The payoff should be apparent. Just as it is impossible to imagine a substance that is form alone or simply matter, it is impossible to imagine choice without taking note of the contributions of both intellect and will. Thus in choice, "the will operates in the act of reasoning, and reason operates in the movements of the will."30 This realization enables Westberg to conclude that when Aquinas says that "choice results from the decision or judgment which is, as it were, the conclusion of a practical syllogism” (ST I-II.13.3), he does not mean to imply that choice is a movement of the will alone to accept or reject the intellect's judgment about what is to be done. Rather, the practical syllogism is the choice itself, where acts of reason and will are combined at each premise and where the conclusion is a judgment that something should be done and a desire to do it. ${ }^{31}$

Westberg recounts the other stages of human action in a similar fashion, pointing out the careful mutuality of reason and will that Aquinas assumes at each stage. The hope in all of this is twofold. First, to frustrate both intellec-

28. Westberg, Right Practical Reason, pp. 82, 122.

29. Westberg, Right Practical Reason, p. 161.

30. Westberg, Right Practical Reason, p. 162.

31. Westberg, Right Practical Reason, pp. 160-61. 
tualist and voluntarist readings of Aquinas's moral psychology, to deny comfort to both Incandela and Gauthier. If Westberg's exegesis is sound, Aquinas cannot be said to give special priority to the intellect in action, if only because its specifications are helpless apart from the will's response. Similarly, Aquinas's talk of the will cannot be said to insert a new feature into Aristotle's account of human action, if only because he does not understand human choice and action "as a process of reasoning followed by an 'act of will' to carry it out." Rather, like Aristotle (EN1139b4), Aquinas considers choice an irreducible combination of reason and desire. ${ }^{32}$

Second, Westberg hopes to make Scotus's voluntarism look unnecessary, the consequence of a flat-footed reading of Aquinas's moral psychology. Indeed, Westberg thinks he has removed a large portion of what Scotus and others find objectionable insofar as his own reading resists all talk of the intellect's priority. However, Westberg also appears to believe that he needs to give those sympathetic with Scotus's voluntarism some assurance that Aquinas's views are compatible with our ordinary sense of what it means for the will to be free. Assurance can be provided, Westberg contends, by noting that Aquinas insists that the will moves of necessity to beatitude alone, which all desire precisely because all quite rightly consider it good universally and from every point of view. All other potential objects of the will fall short of this perfection, which in turn enables the intellect to perceive some deficiency of goodness in each. And of course, if they can be regarded by the intellect as non-goods, they need not be willed. From this conclusion Westberg infers that freedom from necessity in the will extends even to our natural desire to live and to know. For in the mortal life of the pilgrim, all things must be desired in particular, and as particular goods even knowledge and self-preservation fall short of the perfect goodness that compels the will. It follows that only happiness is willed of necessity, which in turn allows Aquinas to guarantee "full scope for freedom and error."33

\section{THE RETURN OF THE REPRESSED}

Does Westberg's reading of Aquinas's moral psychology finally quiet the debate between intellectualists and voluntarists? Has he silenced Aquinas's

32. Westberg, Right Practical Reason, p. 37. Here Westberg follows Anthony Kenny. Both consider Aquinas's treatment of electio the best interpretation we have of Aristotle's treatment of prohairesis. It follows that either Aquinas did not add something new to Aristotle's moral psychology, or Aristotle assumed all along something equivalent to Aquinas's notion of the will. See Anthony Kenny, Aristotle's Theory of the Will (New Haven: Yale University Press, 1979).

33. Westberg, Right Practical Reason, p. 110. Westberg defends this interpretation of Aquinas's response to his voluntarist critics on two occasions (pp. 92-93; 109-10), appealing to two different texts (De Malo iv.2 and In I Peri Herm., lect.14.23-24. Cf., ST I.82.1; I-II.10.2). 
voluntarist critics? Will his exegesis satisfy interpreters of Aquinas with intellectualist sympathies? I think the answer must be no on all counts. In fact, it is difficult to image either side of the debate finding much consolation in Westberg's conclusions.

Voluntarist critics-Scotus and his contemporary comrades-will surely point out that highlighting the mutual causality of intellect and will in Aquinas's account of human action does little to answer their worry about the passive character of the will in Aquinas's hands. If the intellect is ultimately responsible for specifying the object willed and the occasion of its willing, as Westberg, following Aquinas, concedes, then it hardly matters whether acts of intellect and will are woven together or marched in succession. The course of action chosen will be determined by a judgment of the intellect, not by an independent movement of the will. ${ }^{34}$ This reduces the will to a passive power, compelling it to desire as the intellect specifies, which, by voluntarist lights, scuttles its freedom. If Westberg replies that the indeterminacy Aquinas locates in the will guarantees its freedom, the voluntarist critic will surely retort that this indeterminacy contributes nothing to freedom precisely because it is not derived from the will's essence but rather from the intellect's ability to gauge the relative goodness of the objects of choice. As Patrick Lee observes, "Scotus resists any move to make the will's freedom (indetermination) depend on some factor other than itself. The root of freedom . . . is simply the will itself."35

Oddly enough, those sympathetic with intellectualist readings of Aquinas's moral psychology will also find reason to doubt Westberg's account of the will's indeterminacy. They will surely notice that he exaggerates the measure Aquinas finds there. Here the dispute turns on the significance of the distinction between two different acts of the will with respect to the end, velle and intentio. ${ }^{36}$ Westberg takes note of the distinction but fails to understand its significance for Aquinas, collapsing the two as he proceeds through the stages of human action. ${ }^{37}$ In fact, Aquinas keeps the distinction in play precisely at that point where he hopes to specify in what respect the

34. Patrick Lee, "The Relation Between Intellect and Will," p. 321 n. 2, puts the objection bluntly. So long as it is said that the intellect specifies the will, "the common resort to the mutual causality of intellect and will does not answer the problem. . . The problem is this: if the intellect specifies that this object rather than that be willed, then the choice is not free but intellectually determined. If the objection is stated in precisely this way, I think it can be answered only by denying the antecedent."

35. Ibid., p. 328.

36. "voluntas in ipsum finem dupliciter fertur: uno modo, absolute secundum se; alio modo, sicut in rationem volendi ea quae sunt ad finem" (ST I-II.8.3; cf., I-II.12.1 and ad 4).

37. Westberg, Right Practical Reason, p. 133 writes, "it is much more straightforward, more sensible, and more faithful to Thomas to combine . . velle and intentio." The discussion of velle in ST I-II.8-9 disappears altogether from his interpretation of Aquinas's account of human action. 
will is moved to its object by nature, and thus of necessity, and in what respect it is not. Indeed, the distinction is indispensable for making sense of Aquinas's remarks about the will's natural desires. Without it those remarks are unimaginably inconsistent.

On the one hand, Aquinas says that the will is moved by natural necessity to desire, not only our last end, which is happiness, but also those particular ends that belong to us according to our nature, ends that together give our agency its distinctively human character (STI.82.1; I-II.1.7-8). Here Aquinas has in mind our natural desire for self-preservation, for the perpetuation of our species, for knowledge (including knowledge of God), and for friendship (STI-II.10.1; 10.2.3; 94.2). ${ }^{38}$ On the other hand, he insists that the will is not moved of necessity to these particular ends; unlike happiness, their goodness is not perfect, and thus the intellect need not judge them good in every instance (STI.82.2 and ad 1-2; I-II.10.2).

The proximity of these assertions, the first immediately preceding the second at two different places in the Summa Theologiae, makes it impossible to conclude that we face real confusion here, a genuine failure of Aquinas's attention. Better to assume that he is distinguishing two different acts of the will with respect to our final end and to those particular goods that fall under our final end according to our nature. We desire (velle) happiness, as well as particular goods like knowledge and self-preservation, simply and absolutely, and we do so with natural necessity precisely because they are "naturally apprehended by reason as being good, and consequently as objects of pursuit" (ST I-II.94.2). In this respect the ends of human life are fixed, as is our simple and absolute inclination to them. ${ }^{39}$ By contrast, we do not tend to any good-that is, we do not intend to have it - with natural necessity unless it be "good universally and from every point of view" (ST I-II.10.2; I.82.2.1). It follows that of those goods that we are disposed by nature to will simply and absolutely, only happiness is tended to with natural necessity.

Is this sound exegesis? Is Aquinas in fact employing the distinction between velle and intentio in order to say as precisely as he can in what respects the will is moved by natural necessity to its object? Two bits of evidence present themselves. First, in the two questions where he denies that the will is moved of necessity to knowledge, self-preservation, and the like (ST I.82.2 and ad 1; I-II.10.2), much of the talk is of whether the will tends (tendet) to this or that end of necessity. Intention, according to Aquinas, is nothing but "to tend into something," and tending into something entails more than wishing to have it simply and absolutely (ST I-II.12.1). It

38. My remarks here obviously assume an interpretation of Aquinas's treatment of the natural law. See John Bowlin, Contingency and Fortune in Aquinas's Ethics (Cambridge: Cambridge University Press, 1999), chap. 3.

39. "Fines autem recti humanae vitae sunt determinati. Et ideo potest esse naturalis inclinatio respectu horum finium" (ST II-II.47.15; cf. I-II.51.1; 63.1). 
entails actively reaching out toward it and hoping to achieve it by some particular means. Given this distinction, the point Aquinas is trying to make in ST I.82.1-2 and ST I-II.10.1-2 presents itself quite nicely. We do not necessarily intend those particular goods, like health, that we will simply and absolutely according to natural necessity. Of course, we always find health desirable, but we do not always intend to have it even as we wish for it. We might intend to have some other good that, at least in this instance, is incompatible with securing health. Or we might not know how to secure our health in some particular circumstance, which in turn might cause our intention to have it to dissolve into a simple wish for it. Or, as is normally the case with the healthy, we might not be intending anything in particular with respect to our health and yet if asked we would surely insist that health is good and desirable, something we wish to have even if we are not actively tending toward it. ${ }^{40}$

Second, Aquinas remarks repeatedly that the will is related to those ends that it naturally and necessarily desires simply and absolutely as the intellect is related to the principles that it knows naturally (ST I.82.1 and ad 2 ; I-II.8.3; 10.1; 94.2). Moreover, on at least one occasion he contends that velle is to intentio as intellectus is to ratio (ST I-II.8.3). What does he mean to imply with these analogies? In the first, the implication is plain. Just as the intellect knows certain things by nature, so too the will's simple desire for certain ends comes with natural necessity. In the second, the implication is that the will need not intend those same ends with the same necessity. Just as I may not come, by reason's efforts, to grasp every principle that I understand by nature, I do not necessarily intend every end that I will by nature, simply and absolutely (STI-II.8.3). For example, all of us, according to Aquinas, quite naturally understand the principle of noncontradiction. However, it remains an understanding that is simple and abstract until we deploy it in our rational inquiries. Then we comprehend the principle "in the conclusions" that we assent to as a result of the principle (ST I-II.8.3.) Indeed, it is one thing to understand that $p$ and $-p$ cannot both be true at the same time. However, it is quite another to grasp what the principle rationally entails through concluding that one cannot be at work and attend to a sick child at the same time. Similarly, it is one thing to consider knowledge good and to desire it simply and absolutely with natural necessity; quite another to intend to have it now, by these means in this circumstance. For, of course, it may be that in this particular instance this particular intention puts at risk some other good, such as health or wealth, that we not only will simply, but that we prefer.

Failing to appreciate Aquinas's careful use of the distinction between velle and intentio, Westberg underestimates the degree to which Aquinas considers the will determined to some ends and not others, naturally and

40. Note that it is this example that Aquinas uses to distinguish simple volition from intention. See ST I-II.8.3; 12.1.4. 
necessarily, simply and absolutely. Indeed, our intentions may be indeterminate but our simple loves, our natural inclinations, are not. To think otherwise - to think that our most basic loves are indeterminate before they are fixed by choice-is equivalent to thinking that we can constitute the kind of thing that we are by determining the basic loves that give our will its nature and our agency its human character. For Aquinas, this is unimaginable. Our agency is distinguished by our natural desire for a small collection of ends, a desire that is the principal mark of the Creator's hand upon us, an order antecedent to every choice.

Add to this Aquinas's considerable emphasis upon ends that we will simply and absolutely according to second nature, according to acquired habits and dispositions, and suddenly Incandela's intellectualist reading of Aquinas begins to look more and more compelling. ${ }^{41}$ The ends that we desire simply and absolutely are largely given. The will's indeterminacy does not go all the way down. Rather, natural and acquired loves, mediated by the apprehensions of the intellect, determine the context in which the will operates, a context that is, for the most part, assumed and accepted, not chosen.

Of course, the assumption throughout is that the will actually exercises its act, responding to the object presented to it by the intellect, and this need not be the case. As we have noted, the will does control the exercise of its act, just as it controls the acts of the other powers of the soul (ST I-II.9.3). One act of the will can elicit another, just as the will can elicit acts of reasoning or attention (ST I.82.4). But this implies that the will can shut itself down, either entirely or with respect to some particular object. It accomplishes this feat by willing that the intellect not attend to this or that object, either by moving its attention to some other object or by removing its attention from all possible objects. This latter gambit allows Aquinas to insist that, "no object moves the will of necessity," even a perfect good, for it is always in our "power not to think of it, and consequently not to will it actually" (ST I-II.10.2). Yet all of this is done in good intellectualist fashion. The will does not shut itself off by itself. It cannot, for when the intellect presents the perfect or the best, the will's desire follows with necessity (ST I-II.13.6; De Malo iv). For this reason Aquinas insists that the intellect must be turned away from its object if desire is to cease. And of course, the intellect is not turned away by a self-determining act of the will. Rather, the intellect judges that it would be good not to desire. This particular good is then presented to the will, which responds by removing the intellect's attention from some particular good, or, as the case may be, from the good altogether (De Malo iv.7; ST I.82.4.3).

41. Thus Aquinas writes: "When we say that virtue is the order or ordering of love, we refer to the end to which virtue is ordered: because in us love is set in order by virtue" (ST I-II.55.1.4). 


\section{FREEDOM AND REASON}

Throughout, Westberg appears to assume that while voluntarist moral psychologies are wrong-headed, voluntarist complaints with intellectualist readings of Aquinas should be feared. At the very least, voluntarist doubts about the will's freedom in a moral psychology that gives sole authority to the intellect should be taken seriously. When the will is reduced to a passive power, when it cannot step back from the influence of nature, habit, and custom and determine its own ends, when its every movement is determined by the intellect's judgment about the good-its acts may well fall short of freedom. Westberg's alternative treatment of intellect and will is best regarded as an attempt to diffuse this doubt. If, despite his efforts, if flares nevertheless (as indeed it has), and if sound exegesis leads us back to an interpretation of Aquinas's moral psychology that in fact gives priority to the intellect and necessity to the will, then Westberg's assumption presents us with a new exegetical challenge. How might Aquinas respond to the voluntarist's charge that the will cannot be free if it is inescapably dependent upon the intellect and unavoidably situated in nature, habit, and custom?

From the start it should be noted that Aquinas considers the charge groundless on all counts. Appealing to Augustine's authority (De civ. Dv. 10) he insists that our natural desire for certain ends "does not take away the liberty of the will." In fact, he considers the will's natural inclinations to be the "root and principle" of all of its movements, which are, by definition, voluntary (ST I.82.1). In a similar fashion he appeals to Aristotle's authority (EN 1105a30-1105b1) in order to insist that a virtuous habit in the will does not diminish the voluntary character of its actions. Quite the contrary, a virtuous action, by definition, must be voluntary (ST II-II.58.1). And finally, we have already seen how he considers the voluntary a species of the rational, which in turn prevents him from concluding that the will's freedom is threatened when determined by the intellect (ST I-II.6.1-2). Indeed, he thinks that the will is the source of voluntary action precisely because the intellect directs it to the good.

The exegetical difficulty comes in saying precisely what account of the voluntary Aquinas assumes. The task becomes all the more difficult once we notice that he considers deliberation the principal sign and precondition of the perfectly voluntary (ST I-II.1.3; 6.2 and 2 ). In fact, inconsistency threatens, for, of course, the ends to which we are naturally disposed, whether internally by virtuous habits or externally by providence, are not subject to deliberation. Here I can only sketch a brief reply, but even the outlines of an answer are illuminating.

Aquinas considers deliberation the mark of the perfectly voluntary because it yields a distinctive kind of knowledge of the end in the agent who 
acts. Of course, even those actions that fall short of the perfectly voluntary originate in knowledge of the end, and thus even children and animals can be said to act voluntarily (ST I-II.6.1). Nevertheless, their knowledge of the end is imperfect. It "consists in mere apprehension of the end, without knowing it under the aspect of the end." By contrast, the perfect knowledge of the end that distinguishes the perfectly voluntary actions of rational agents "consists in not only apprehending the thing that is the end, but also in knowing it under the aspect of the end, and the relationship of the means to that end" (ST I-II.6.2; cf. 1.2 and ad 1). Since Aquinas expends little effort explaining what this difference entails and how deliberation makes it, we will have to do the work for him. Our only hint is that children and animals are moved by less than perfect knowledge and thus presumably without deliberation.

Children do consider and decide. Even toddlers confront options: apple juice or orange, red shirt or green, go with Mom or stay with Dad, play with trucks or read books, and so on. But what toddlers cannot do, and will not do until they are somewhat older, is reflect on the relative merits of this or that intended end. They can know that reading books is a desirable activity, an end worth pursuing, and it is this knowledge, this "principio intrinseco," that precipitates their actions (ST I-II.6.1). And, of course, they can decide which books they like to read. However, they cannot ask how this activity, this end, stacks up against others. They cannot give reasons that explain why they rank it among other possibilities as more or less important. Their immature deliberations do not lead them to this kind of reflection upon their intentions. Their fears do not compel them to it. As a result they are incapable of having the self-conscious realization that the goodness of any particular end may well be defeated in some instance by the goodness of another.

All of this should be apparent to those who have tried to convince a toddler that sleeping is an activity whose goodness defeats all others after a certain hour. He has no interest in that kind of reflection. Indeed, he is moved almost immediately, almost spontaneously, toward his intended end (subito movetur in ipsum) (ST I-II.6.2). No other possibilities slow him down. It should also be apparent that Aquinas does not consider deliberation a simple means-to-end enterprise, at least not in fully rational agents. Rather, deliberation must also entail reflective attention to the relative goodness of an intended end as it compares to other ends that are willed simply and absolutely, either by first or second nature.

It is this kind of deliberate reflection upon our simple and natural loves that generates the distinctive knowledge of the end that, by Aquinas's lights, characterizes the perfectly voluntary. It also blunts whatever necessity those loves might have. Reflecting on our natural love for some particular end, comparing it with other options, other loves, we come to claim it as our own. We come to desire it because Providence or habit directs our love in one way and not another, and because we confirm the goodness of what we love 
by nature in a judgment that it is in fact good and thus desirable. Only then can we be said to pursue it with "perfect knowledge," for only then will we understand its relative goodness and act for the sake of that end because of that knowledge. Only then can we be said to move ourselves to what we love by nature, for only then will our actions originate in our judgments about the good. 42

If this is sound exegesis, then it appears that Aquinas deems this kind of deliberate reflectiveness the distinguishing feature of human agency as such. Of course, he does not think that deliberation precedes every human action, but he does believe that the deliberations we do pursue bring us, over time, to subject our natural loves to this kind of reflective appraisal. Moreover, he believes that deliberate attention to those ends that we love by second nature, by custom and habit, frequently lead us beyond the appraisal of individual loves to a more thoroughgoing assessment of our moral posture in the world. Indeed, following Aristotle, he thinks that an agent can be counted among the virtuous only insofar as her actions assume this kind of global assessment. In particular, her deliberations must bring her to conclude that the virtues are good and desirable in themselves, indispensable in the best kind of life. An action unaccompanied by reflective knowledge of this sort, even an action motivated by an intention that the virtuous themselves share, cannot be considered virtuous. Thus the just do not simply pursue just ends by habit, they also know the relative merits of acting justly. Indeed, they come to this reflective knowledge, this settled assessment, through "deliberating about the end" (deliberans de fine) that their habit disposes them to pursue as if by nature. ${ }^{43}$ Similarly, the courageous must not only respond to difficulties and dangers well, at times without forethought (ST II-II.123.7), they must also come to recognize, at times retrospectively, that courageous activity is itself worth pursuing ( $S T$ II-II.123.7).

Virtuous action assumes knowledge of the end that is reflective in this special way, while human action in general assumes knowledge of the end that is reflective in some way. In each instance, reflectiveness, either as forethought or as retrospective appraisal, yields perfect voluntariness. It follows that free agency for Aquinas is not equivalent to indeterminacy,

42. The connection between rational reflection, second order judgments about the good, and acting with the knowledge that is characteristic of the voluntary appears to have been Aquinas's settled view from early on. In the treatment of voluntary agency found in De vert. 24.1 he writes, "Man, judging about his course of action by the power of reason, can also judge about his own decision inasmuch as he knows the meaning of the end, and the relationship of the one with reference to the other. Thus he is his own cause not only in moving but also in judging." By contrast, "brutes do not judge about their own judgment but follow the judgment implanted in them by God" (nec bruta iudicant de suo iudicio, sed sequunter iudicium sibi a Deo inditum).

43. See EN 1105a31 and ST II-II.58.1; 123.7. 
whatever its origin, whether in the will as Scotus contends or in the intellect as Westberg appears to believe. Nor is it the ability to intend this or that in the present or to look back from a completed action and know that a different course could have been intended. Rather, voluntary agency entails acting for the sake of some end because it is known to be good deliberately, reflectively. Of course, the indeterminate character of our intentions is a precondition for this kind of knowledge (ST I-II.6.2.3). So is the intellect's ability to be "indifferently disposed" to those potential objects of intention that fall short of perfect goodness. Together these two indeterminacies create the field of possibility where reflection can proceed, where the relative goodness of this or that potential object of intention can be assessed against other possibilities. They also explain why we are able to know the ends that we intend in this reflective fashion while animals cannot. ${ }^{44}$ Nevertheless, it is reflective knowledge of the end that constitutes our freedom, not the indeterminacy that makes that kind of knowledge possible, not the ability to do otherwise in the present, not the confidence that one could have done otherwise in the past. ${ }^{45}$

Once we realize that Aquinas locates free agency in our reflective knowledge of the good we can begin to see that his intellectualist moral psychology presents no threat to the will's freedom. Quite the contrary it enables him to consider the will bound on all sides by necessity, both natural and acquired, and yet free nevertheless. By the same token, we can begin to see how he can insist that the perfectly good and the indisputably best place necessity upon the will without diminishing its freedom. In each instance, the will is moved to act for the sake of some object because it is known to be good, and it is this knowledge, this precipitating judgment, that secures the voluntary character of what is done.

Again, Aquinas does little to help us make sense of this, and yet I think the intuition at work here is rather ordinary. We frequently find ourselves in circumstances that compel us to will some end because of the character of our judgment about its goodness. We must act, and yet because the necessity comes from us, from our judgment, and because the object that moves the will is judged good by us, doubts about the voluntariness of what is done are difficult to sustain. Imagine I return home one evening and find my house on fire. Imagine my children are asleep inside. Given these circumstances, given opportunity to act, given the character of my habitual love for my children, and given my other dispositions and affections, I must will their safety. I must do something to rescue them. It would be, quite

44. More often than not Aquinas refers to indeterminacy in the intellect and will in order to distinguish the knowledge of the end that we are able to muster from the kind that animals can. Cf. ST I-II.6.2.2 and I-II.30.3.2.

45. For a modern treatment of voluntary agency along similar lines, see Harry Frankfurt, "Freedom of the Will and the Concept of a Person," Journal of Philosophy 68 (1971): 5-20; and Susan Wolf, Freedom Within Reason (Oxford: University Press, 1990). 
literally, impossible for me to intend some other end in this instance. Moreover, it would be, I suspect, quite difficult to maintain that my intention to rescue them is involuntary despite the fact that habit and circumstance conspire to compel me. I act for the sake of an object I judge good, an object I have ranked among others, and it is this reflective knowledge of its goodness that moves me to act. I must act. Given who I am I can do no other. And yet, because the necessity comes from me-from my own judgment about the good-doubts about the voluntary character of what I do are hard to sustain. I act because of my reflective judgment about the good and the best. What more could possibly be required to certify my freedom?

Perhaps that I could have done otherwise? For those with voluntarist sympathies, it is this possibility that free agency assumes. Of them I suspect Aquinas would ask why this possibility must attend every action that we count among the voluntary. Indeed, if an account of the voluntary cannot accommodate the commonplace necessity that follows the convergence of circumstance, habit, and judgment, then perhaps we should revise that account. It would be better to regard the theory impoverished than to consider a large measure of our agency enslaved. In fact, in this instance, slavery would be in evidence only if I had done otherwise. If I had backed down the driveway and slipped quietly away, and if we assume my character remained untouched, my affection for my children undiminished, then it is unlikely that we would speak of my uncommon freedom. Rather, I suspect we would assume that some necessitas coactionis, some vile compulsion-temporary madness, drugs dropped in my coffee, a gun to my head, or the like-was dragging me about, doing violence to my will (ST I.82.1).

Still others might point out that the state of my will with respect to my children originated in a habit whose sources I cannot control: the simple and absolute desire for the well-being of my offspring that Providence provides, the training and experience that transformed this desire into habitual love. 46 To them I suspect Aquinas would reply that my loves are my own, whatever their origin, so long as they are confirmed in reflective judgment. If the critics retort that reflective judgment does little to make these loves my own precisely because I am disposed by nature and habit to confirm their goodness, then I suspect Aquinas would point out that our simple and absolute desires are multiple and competing, that there is no natural hierarchy among them, and that natural velle does not necessarily yield concrete intentio. ${ }^{47}$ It follows that while my rational reflections on the

46. Aquinas calls our simple desires that Providence provides the nurseries (seminalia) of virtuous habits (ST I-II.63.1).

47. Some exegetes dissent and argue that Aquinas considers our natural inclinations hierarchically ordered. In the hierarchy, they insist, he locates the prescriptive content of our nature. See Ralph McInerny, Aquinas on Human Action: A Theory of Practice (Washington, D.C.: The Catholic University of America Press, 1992), pp.120-22. My doubts are spelled out in Bowlin, Contingency and Fortune, chap. 3. 
goodness of what I love will indeed confirm my natural inclination to care for my offspring, I may well conclude that the other objects of natural affection are in fact more desirable, more worthy of being translated into concrete intentions and settled habits. Indeed, it is this kind of judgment that brings some to forego having children, others to ignore the ones they have. Reflection upon loves secured by acquired habit proceeds under the same possibility.

Of course, with these replies Aquinas would not remove the necessity that circumscribes my willing. He would merely diminish its bite. My natural loves may well be multiple and competing, but they are still given. With rational reflection I may be able to confirm my natural inclination to care for my offspring and thus in a sense make that inclination my own, and yet necessity remains precisely because reflection takes place against a backdrop of unquestioned natural loves. Indeed, I may well come to believe that some objects of natural affection are more desirable than others, but I must nevertheless consider all of them desirable in some fashion. My nature allows me no more wiggle room here than it does when I am offered an object that is known to be good universally and from every point of view. In each instance, my will responds with desire, natural and necessary.

Still, there is no loss of freedom here precisely because it is the good, mediated through knowledge of it, that generates necessity in the will. The good is what we want, and thus knowledge of it cannot coerce the will's response. When we desire (velle) some object because of our intellect's judgment that it is good, when we intend to achieve it because we know it to be good, surely we act without violent compulsion. And this freedom remains even when the will's desire could not be otherwise, for it is our judgment about the measure of goodness in the object willed that yields the necessity. When we conclude that an object's goodness defeats all others, either simply or in this or that instance, desire follows of necessity for it is the good that we want. For the same reason no coercion is involved, no freedom lost, even as our judgment about the goodness of the object makes it impossible to withhold desire.

If the final retort is that knowledge of the good can do little to save freedom precisely because we are disposed by Providence to consider some things good but not others, to desire (velle) some objects but not all, Aquinas can simply remind his critic that we cannot modify the inclinations characteristic of our kind, we cannot transform our basic human orientation toward the good. Indeed, to think that we must muster this kind of autonomy, this power of self-creation, before we can consider ourselves free is foolish, prideful. Thus he writes: "it is essential to the voluntary act that its principle be within the agent: but it is not necessary that this inward principle be the first principle unmoved by another" (ST I-II.9.4.1). Surely, it is unnecessary that we acquire the kind of authority over our natural 
inclinations that distinguishes God the creator before we can call what we do our own. ${ }^{48}$

\section{SIN: ORDINARY AND ORIGINAL}

One last worry remains, one last obstacle for this intellectualist treatment of human action to overcome: accounting for moral weakness. If Aquinas concedes that the will must desire an object whose goodness, according to the intellect, has no rival, how then can he account for those ordinary instances when we resist reason's judgment and pursue an object that falls short of the best? ${ }^{49}$

Here one might imagine Aquinas resorting to talk of an independent will, one that can resist reason and generate $\sin$, but he does not. Instead, he accounts for incontinence in strictly intellectualist terms, with the intellect leading and the will following. The details of that account, along with its antecedents and merits, have been discussed elsewhere and need not be repeated. ${ }^{50}$ For now it should be sufficient to point out that Aquinas makes his

48. In his earlier work Aquinas puts the point in just these terms: "But no one would say that man does not have free choice merely because he cannot will or choose in the manner in which God or an angel can" (De vert. 24.1.3). The moral is plain enough. An intellectualist moral psychology requires a certain kind of humility, the voluntarist alternative a certain kind of hubris.

49. For Scotus this presents no special difficulty. Because the will is self-determining it can always resist the intellect, even when presented with "that greatest beneficial good, namely perfect happiness" (Ordinatio II.6.2, Wolter, Duns Scotus, pp. 464-65). Indeed if the will could not resist, if the intellect determined its desires, then by Scotus's lights it would not be free. It should also be noted that Scotus reverses the drama of resistance, transforming the stubborn intellect into villain, the independent will into hero. When the intellect proposes courses of action that secure benefit at the expense of justice, to which the will is also inclined, resistance should ensue. Thus Scotus writes that the will, "through its liberty could moderate itself in willing. It could do so as regards that volition towards which it is inclined by the affection for the advantageous, even though it might be most inclined to will the advantageous. And from the fact that it could moderate this, it is bound to do so according to the rule of justice it has received from a higher will. It is clear, then, from this that a free will is not bound in every way to seek happiness (in the way a will that was only an intellective appetite without liberty would seek it). Rather it is bound, in eliciting its act, to moderate the appetite qua intellective, which means to moderate the affection for the advantageous, namely, lest it will immoderately" (Ordinatio II.6.2, Wolter, Duns Scotus, p. 470-71). It follows that sin-willing immoderately-is, quite literally, a special kind of weakness in the will. Not the will's inability to desire what reason judges good, but rather a passive response to the intellect's faulty judgment, a failure to withhold desire for a good whose pursuit yields injustice.

50. See Bonnie Kent, "Transitory Vice: Thomas Aquinas on Incontinence," Journal of the History of Philosophy 27 (1989): 199-223. 
case by appealing to rather ordinary psychological assumptions. Our judgments about the good can be multiple, our minds mixed about its general principles and particular instantiations. Disordered passions are normally the cause of this confusion, as they distort, distract, and divide reason's judgment of matters both general and particular. ${ }^{51}$ They can also interrupt the ordinary transition from judgment about the good to rational desire of it, thus making it possible for a competing judgment to precipitate action with the aid of a competing desire. ${ }^{52}$ Incontinence occurs when passions of this sort have this kind of effect. It follows that Aquinas does not explain moral weakness by appealing to a will that can resist reason, but rather by noting that reason can be at odds with itself when passions run unchecked.

With this last worry answered, can we safely conclude that Aquinas's moral psychology is intellectualist all the way down? In fact, we cannot. No doubt, we would be able to draw this conclusion had Aquinas confined his inquiries to human action in via. However, his explanatory aims extend to Eden, whose drama presents a difficulty that requires a momentary voluntarist detour. The difficulty is this: what accounts for "the first sin of the first man" (ST I-II.81.1)?53 Explaining subsequent moral failure presents no equivalent difficulty, no equivalent need for a voluntarist turn. Its proximate cause is mistaken judgment about the good. Its remote cause is inordinate appetite for mutable goods, which in turn distorts, distracts, and stupefies the intellect and precipitates its mistaken judgments (ST I-II.75.1-2). When inordinate appetite for mutable goods becomes constant and the intellect's confusion perpetual, a habit forms and sin becomes malicious (ST I-II.78.1-2). It follows that ordinary moral failure requires a certain independence of passion from intellect (ST I-II.56.4.3), and yet it is precisely this independence that Aquinas considers absent in Eden. Grace was bestowed upon its inhabitants and made them right. This original rectitude consisted in "reason being subject to God, the lower powers to reason, and the body to the soul" (ST I.95.1). As a result, "the inferior appetite was wholly subject to reason: so that in that state the passions of the soul existed only as consequent upon the judgment of reason" (ST I-II.95.2). How then did sin enter paradise?

Perhaps the intellect of the first man was deceived about the good on its own? But Aquinas rules this out. The intellect, he insists, "is ever true;

51. Thus Aquinas locates the origin of moral weakness in the passions ( $S T$ I-II.77.1-3).

52. Disordered passions disrupt the ordinary transition from the intellect's assent that some object is good, either in general or in particular, to the will's consent that it is. Thus the incontinent give assent to competing judgments about the good, in general and in particular, while consenting to only one. See ST I-II.15.1 and $a d$ 3; 77.3.3.

53. For evidence that the late thirteenth-century debate was not only about freedom and responsibility, but also about Adam's first sin and our own moral weakness, see Kent, Virtues, pp. 114-15, 174-98. 
and hence it is never deceived of itself" about what it knows. Rather, deception must come from the influence of "some lower faculty," antecedently disordered and disordering (ST I.94.4; cf. SCG III.108.4-5). No doubt, cognitive difficulties can arise and the intellect can fail to acquire knowledge of this or that. Its rational inquires might go astray, it might apply the wrong definitions to the wrong things, or the definitions that it employs might themselves be false (ST I.85.6). But neither difficulty nor deception confounded the intellect of the first man, who had knowledge of all things that human beings are able to know "by divinely infused species" (ST I.94.3.1) and whose "lower powers remained subject to reason" by "a supernatural endownment of grace" (ST I.95.1).

Nevertheless, the first man did sin and his sin was pride (ST II-II.163.1). Pride "is inordinate desire of one's own excellence" (ST II-II.162.2). In this instance, the excellence desired-knowledge of good and evil and power over one's own happiness (ST II-II.163.2)—could not be had without turning away from God in disobedience (ST I-II.84.2; II-II.163.1.1). But how did this inordinate desire come into the will? If we assume an intellectualist account of human agency, as Aquinas normally does, then we must imagine the intellect passing judgment on two goods, personal excellence and freedom from divine rule, and presenting them to the will as objects more desirable than fellowship with God. Yet this blunder about the best, about the good that compels the will's desire, is unimaginable in Eden. It implies that the first man either did not know what his good actually entailed, either in general or in particular, was insufficiently attentive to some feature of the good that he should have known, or was deceived about what he did know, and Aquinas refuses each possibility. ${ }^{54}$ Indeed, even the serpent's suggestions could not by themselves bring the first man to a false judgment about the good (ST I.94.4.1; II-II.163.1.1). Something else was needed to make its slippery persuasions effective.

Here Aquinas fails to come clean, although he provides the hints we need to help him do so. Appealing to Augustine's authority he argues that the first man was effectively deceived by the serpent because he was already "puffed up with pride" (elatus superbia) (ST II-II.163.1.1; cf. I.94.4.1 and 5).55 What this prelude to deception actually entails Aquinas does not say, at least not directly. He does, however, remark that because the first man resided under a "special favor of grace . . no creature outside himself could harm him against his own will (contra propriam voluntatem)," even the devil (ST II-II.165.1). The implication, of course, is that the serpent's persuasions

54. He writes: "Now man was so appointed in the state of innocence, that there was no rebellion of the flesh against the spirit. Wherefore it was not possible for the first inordinateness in the human appetite to result from his coveting a sensible good, to which the concupiscence of the flesh tends against the order of reason" (ST II-II.163.1).

55. In ST II-II.163.1.1 he appeals to Dial.QQ.1xv.4, in I.94.4.1, In Gen. ad Litt.xi.30. 
were effective precisely because the will of the first man, being puffed up with pride, had already turned toward sin on its own. Aquinas's remarks about the special character of pride bear out this suggestion.

Like all sin, pride has two parts: a turn toward some mutable good and a turn away from the immutable. Yet, pride distinguishes itself from all other sins insofar as it turns the sinner away from God for no intelligible reason, for the sake of no other good. Aquinas writes:

[I]n other sins man turns away from God, either through ignorance or through weakness or through desire for any other good whatever; whereas pride denotes aversion from God simply through being unwilling to be subject to God and His rule.... Wherefore aversion from God and His commandments, which is a consequence as it were in other sins, belongs to pride by its very nature, for its act is the contempt of God.” (ST II-II.162.6)

In pride, conversion to a mutable good and aversion from the immutable good are teased apart, the latter preceding the former. Apparently this autonomous aversion, this demonic turn of the will away from God, disposed the first man to assent to the serpent's deceptions and turn toward a mutable good, thus completing the act of pride. Only this can explain how Aquinas can insist that pride both did (ST I.94.4.1) and did not precede the promptings of the serpent (ST II-II.163.1.4). Only this can account for his remark that, "the woman was deceived before she sinned in deed, still it was not till she had already sinned by interior pride" (ST I.94.4.1).

Aquinas's reticence about his momentary voluntarism hardly surprises. Not only is it inconsistent with the intellectualism that holds sway in the rest of his moral psychology, it also undermines every effort to account for the first sin. If Adam's will moves itself-that is, if it does not move for the sake of some end judged good by the intellect-then no reasons explain what it does. ${ }^{56}$ No sense can be made of its turning away from the good that Adam knows to be best. Nothing intelligible can be found in its desire to forsake the one true source of human felicity, the fellowship with God that obedience yields. No doubt, Adam's sin becomes intelligible once he turns toward the lesser good that he mistakenly regards as best, and yet this mistake is itself unimaginable apart from the will's unintelligible rejection of the good that he quite rightly considered best. Nevertheless, Adam's self-moving will is indispensable for two reasons. It allows Aquinas to place the first sin and the fall from grace where they belong, among the articles of faith that regard the sanctification of the creature (ST II-II.1.8.4), unintelligible to us in via and yet subject to our assent by God's gracious assistance (ST II-II.1.4). It also

56. In fact, the unintelligibility of what it does on its own implies that the will's self-movements are not actions. For actions are intelligible as such, something done for the sake of some end judged good (ST I-II.1.1). 
enables him to locate the origin of evil in us, thus releasing God from responsibility for Adam's first sin and its consequences. Note, this too falls among the articles of faith. If it makes little sense to consider Adam's will an independent source of action, then it will hardly make sense to hold him responsible for what he does by will alone. Still, natural reason can regard this unintelligible source of dubious "action" as a locus of evil in creation, if only because a self-determining will has no necessary commitment to the good. As Iris Murdoch points out, Milton's Lucifer was self-determining in precisely this way. ${ }^{57}$ So too was Aquinas's Adam.

Here Aquinas follows a track laid down by Augustine. Voluntarism is employed in the service of theodicy then abandoned once sin is established in creation. To the Manichees' charge that God the creator colludes in this world's evils, Augustine argues that, "nothing makes the mind a companion of cupidity, except its own will and free choice."58 As the years pass, he discovers what Aquinas assumes: that a will unassisted by the intellect's judgment about the good cannot cause intelligible action (Conf. II.v.11). Like Aquinas he now resorts to an intellectualist treatment of human action in order to account for ordinary moral failure.59 The will is naturally disposed to love what the intellect considers good, and yet this side of Eden both are, "twisted away from the highest substance, you God, towards the lowest things" by consuetudo carnalis (Conf. VII.xvi.22), by habitual desire for and delight in sensible goods (Conf. VII.xvii.23).60 And, like Aquinas, he now resorts to a voluntarist treatment of human action selectively, most prominently in his own private problem with forbidden fruit. He struggles to describe his short career among pear thieves as the consequence of a will that turns away from the good for the sake of no other. Had intellect and passion been contributing causes, the action would have been done for the sake of some end, such as pleasure or profit, and yet Augustine can locate no such motive for his theft. Conceding this, his action becomes unintelligible and thus unimaginable. If we cannot imagine someone murdering another for no reason beyond the pleasure taken in the evil itself, how then can we imagine thieving that desires no good (Conf. II.v.11)? Puzzled, he turns the matter over and over, at first seeking an explanation for his actions in desire for this or that and then refusing all possibilities and moving on (Conf. II.x.18).

57. Iris Murdoch, The Sovereignty of the Good (London: Ark Paperbacks, 1985), p. 80 .

58. De lib. arb.I.x.21, from On the Free Will, in Augustine: Earlier Writings, ed. and trans., J. H. S. Burleigh (Philadelphia: Westminster Press, 1953), p. 125; cf., Conf. VII.iii.4-5.

59. For an explication and defense of Augustine's intellectualism see James Wetzel, Augustine and the Limits of Virtue (Cambridge: Cambridge University Press, 1992).

60. For more on habit, delight in sensible goods, and human wickedness see Conf. III.viii.16; VI.viii.13, xii.22. 
Theodicy motivates this voluntarism as well. The self-determining will makes the disorder in us our own. It turns us to inferior things and precipitates our habitual passion for them. It also generates our mysterious dependence upon God's gracious assistance. Because we are capable of acting in ways that are at once sinful and unintelligible, virtue and self-knowledge will always escape our reach in the absence of divine aid. We lead a rotten, monstrous life, which only God can redeem (Conf. II.vi.14). We are a grande profundum that only God comprehends (Conf.IV.xiv.22). The self-determining will makes this much plain.

\section{CONCLUSION}

The irony in this should be apparent. Voluntarist critics of Aquinas, both medieval and modern, normally cite his departure from Augustine and his dependence upon Aristotle as the source of his failure. In fact, Aquinas stands closer to the mature Augustine than they imagine, not because he is a voluntarist, but rather because both refer to a self-determining will infrequently, only as theological commitments create descriptive demands that their everyday intellectualism cannot meet. Both consider the independent will, like the fall from grace that it causes and explains, a theological notion. Neither consider it a permanent psychological feature, an indispensable anchor of free agency in via.

If this conclusion is sound, then we will have to reconsider the placement of these two figures in the history of ethics. We will also have to rethink how we approach Aquinas's moral theology. Normally exegesis begins as conflicts are noted among the traditions he employs as he develops his own views. Normally it is assumed that these conflicts must be overcome, diffused, or explained away and that Aquinas's achievement should be measured, at least in part, by his success in this effort. Friends praise his ability to bring jumbled sources together into a coherent view. ${ }^{61}$ Critics doubt that coherence can be forced upon incommensurable traditions. 62

Surely there is merit in this. Disagreements of various kinds do indeed cut across Aquinas's sources. Problems of compatibility and consistency do arise, and Aquinas does address them, as he insists he must, particularly when authoritative sources depart from Christian orthodoxy (SCG I.7). Nevertheless, if my account of this portion of Aquinas's moral psychology is sound, then we can no longer assume that resolving abstract conflicts

61. Alasdair MacIntyre, Whose Justice? Which Rationality? (Notre Dame: Notre Dame University Press, 1988), pp. 164-207.

62. Henry Jaffa, Thomism and Aristotelianism: A Study of the Commentary by Thomas Aquinas on the Nicomachean Ethics (Westport, Conn. Greenwood Press, 1952). 
among competing authorities is the principal task he sets for himself, even as he takes it up now and then. Rather, as Servais Pinckaers remarks, Aquinas regards moral theology as practical commentary on the Gospel, designed to describe the contours of a faithful Christian life. ${ }^{63} \mathrm{He}$ employs multiple sources precisely because commentary cannot proceed well without them, given its multiple aims. When conflicts among sources arise, we should not be surprised as he leaves some of them in place. Some are intractable, not in principle, but quoad nos. Biblical commentary regards things that human beings cannot comprehend without divine assistance, and thus some of the concepts and ideas we use in its service will inevitably generate conflicts with the conceptual resources that human reason supplies. That Aquinas concedes the obstinate character of some of them does not mean that he commits himself to the truth of contrary propositions. Rather, his concession is to our short views and fallen nature, and his desire is that commentary proceed nevertheless. When he leaves a particular conflict in place, we should assume that concern about incompatibility among the sources he employs has been subordinated to his desire that commentary go forward "however thin and weak the sight may be" (SCG I.8). Moreover, we may discover, as we have in his moral psychology, that abstract conflicts are made inconsequential by the pragmatic demands and concrete details of biblical commentary. It follows that our exegetical efforts should no longer begin by asking whether he can resolve the conflicts among the sources he employs. Rather, we should ask, what particular descriptive tasks lead him to employ sources that happen to conflict and what becomes of a conflict once its sources are put to good use?

63. Pinckaers, Sources of Christian Ethics, p. 163. 